\title{
Nutritional Value of Crested Wheatgrass for Wintering Mule Deer
}

\author{
P.J. URNESS, D.D. AUSTIN, AND L.C. FIERRO
}

\section{Abstract}

The nutritional value of crested wheatgrass in the fall to spring diet of mule deer was determined from in vivo and in vitro digestibilities, a field grazing trial, and crude protein analyses. Its dietary significance was evaluated by comparing the known diet with and without the grass component. Findings indicated fall regrowth and spring growth of crested wheatgrass favorably affected the nutritional plane of mule deer on winter range dominated by big sagebrush having intermingled seedings of this exotic grass.

Sagebrush-grass habitat constitutes an important part of Intermountain Region winter ranges used by mule deer. Although browse comprises the majority of the winter diet (Kufeld et al. 1973), grass is often an important component (Leach 1956, Dietz et al. 1962, Hungerford 1970, Robinette et al. 1973), particularly during spring (Julander 1958, Trout and Thiessen 1973, Neff 1974, Hansen and Reid 1975). Because the digestibility of available forage decreases in winter (Ammann et al. 1973), and the digestive tract of mule deer is proportionately small (Short et al. 1965, Schoonveld et al. 1974), the potential value of green herbaceous material may be highly significant (Moen 1978). It was the intent of this study to assess the nutritive value of crested wheatgrass (Agropyron desertorum) in the winter diet of mule deer, recognizing that it tends to produce greater amounts of fall regrowth and earlier spring growth than most native grasses (Plummer et al. 1968). Moreover, it has been widely seeded on scattered foothill rangelands throughout the region, and thus its potential to affect wintering deer is high.

\section{Study Area}

The study was conducted on big sagebrush (Artemisia tridentata vaseyana)-crested wheatgrass rangeland near Hennifer in northern Utah. The area is an important winter range for deer and is grazed in late spring and early summer by livestock. A wildfire, in 1965, largely removed the dense big sagebrush community which characterized the site, and the area was seeded to crested wheatgrass. Although crested wheatgrass continued to dominate production during this study, big sagebrush, Douglas rabbitbrush (Chrysothamnus viscidiflorus), and other browse species were increasing, while the native grasses, primarily Indian ricegrass (Oryzopsis hymenoides) and bluegrass (Poa spp.), were sparse but apparently stable.

\section{Methods}

A conventional in vivo digestion balance trial using 4 tame mule deer and metabolism cages as described by Harris (1970) was conducted during the spring growth period, April 1976. Deer were fed a pure diet of hand collected, green crested wheatgrass for 20 days, with the first 10 used as a dietary adjustment period (Mautz 1971). Feed, feces, and urine were weighed daily and used in

\footnotetext{
Authors are associate professor, wildlife biologist, Department of Range Science, Utah State University, Logan 84322; and Director, Rancho Exp. La Campana Station, Instituto Nacional De Investigaciones Pecuarias, SAG, APDO, Postal 682, Chihuahua, Chih. Mexico.

Research was funded by Utah Division of Wildlife Resources, Federal Aid Project W-105-R.

Manuscript received December 14, 1981.
}

nitrogen and gross energy determinations (Fierro 1977).

A 10-day field trial to estimate intake was conducted within an enclosure containing a nearly pure stand of crested wheatgrass during late April, 1979. Four tame deer, different from those used in the in vivo trial, were acclimatized for several weeks previous to the trial. Body weights were taken before and after the trial. Daily consumption during the trial was determined by using (1) simulated hand-plucked bites, (2) mean observed number of bites taken per minute, and (3) number of minutes spent grazing per day. This latter figure was obtained during a 24-hour observation period using scan sampling (Altmann 1974) at 4-minute intervals.

Forage samples of plants known to constitute $1 \%$ or more of the diet of deer grazing foothill ranges on a free-ranging basis (Austin and Urness, in press) were collected during the fall, winter, spring green-up, and spring periods. Crude protein (Harris 1970) and in vitro digestibility (Tilley and Terry 1963) were determined. Rumen inocula for two in vitro digestion trials were obtained from tame elk, fed green crested wheatgrass, and deer collected at the study site. Differences between trials were insignificant and mean digestibilities are reported.

\section{Results}

Results from the crested wheatgrass in vivo and field trials were similar (Table 1). Deer weight changes during the trials were not significant except during the in vivo trial for deer \#2, which had some digestive problems that strongly and negatively affected the mean results. The average daily dry-matter consumption was $1.58 \%$ of body weight for the in vivo trial and $1.73 \%$ during the field trial. Weight increased during the field trial but decreased during the in vivo trial. In vivo dry matter digestibility coefficients were greater than $55 \%$ and no significant differences were found among deer. Although deer $\# 2$ showed a negative nitrogen balance, the mean balance was positive.

Table 2 shows the percent crude protein and in vitro digestibility along with the dietary contribution of available forages for freeranging deer with access to both burned-seeded and unburned sites. Crested wheatgrass was determined to be a nutritionally valuable forage throughout winter. During all 4 periods it was higher in percent crude protein than any other available forage. Its contribution was particularly important during fall and spring green-up periods when its dietary occurrence raised the mean

Table 1. Results from created wheatgrass in vivo digestibility and field trials: 10-day change in weight (\% body weight), daily dry-matter consumption ( $\%$ body weight), in vivo dry matter digestibility $(\%)$, and nitrogen balance ( $8 /$ day).

\begin{tabular}{|c|c|c|c|c|c|c|}
\hline \multirow[b]{2}{*}{$\begin{array}{l}\text { Deer } \\
\text { No. }{ }^{1}\end{array}$} & \multicolumn{4}{|c|}{ In vivo trial } & \multicolumn{2}{|c|}{ Field trial } \\
\hline & $\begin{array}{c}\text { Body } \\
\text { weight }\end{array}$ & $\begin{array}{l}\text { Consump- } \\
\text { tion }\end{array}$ & $\begin{array}{c}\text { Digesti- } \\
\text { bility }\end{array}$ & $\begin{array}{c}\text { Nitrogen } \\
\text { balance }\end{array}$ & $\begin{array}{l}\text { Body } \\
\text { weight }\end{array}$ & $\begin{array}{c}\text { Consump- } \\
\text { tion }\end{array}$ \\
\hline $\begin{array}{c}1 \\
2^{2} \\
3 \\
4 \\
\text { Mean }\end{array}$ & $\begin{array}{r}0.0 \\
-6.2 \\
0.0 \\
-1.4 \\
-1.9\end{array}$ & $\begin{array}{l}1.86 \\
1.17 \\
1.71 \\
1.59 \\
1.58\end{array}$ & $\begin{array}{l}64 \\
55 \\
64 \\
66 \\
62\end{array}$ & $\begin{array}{l}+1.57 \\
-1.02 \\
+0.80 \\
+1.11 \\
+0.61\end{array}$ & $\begin{array}{r}+0.3 \\
+0.9 \\
0.0 \\
+5.0 \\
+1.5\end{array}$ & $\begin{array}{l}1.46 \\
1.68 \\
1.36 \\
2.43 \\
1.73\end{array}$ \\
\hline
\end{tabular}

'Deer used in the two trials were not the same animals.

${ }^{2}$ Deer $\# 2$ in the in vivo digestion balance trial had some digestive upset as evidenced by diarrhea and the significantly lower values. 
Table 2. Percentage crude protein and in vitro dry matter digestiblity of winter range forages consumed by mule deer during fall, winter, spring green-up, and spring periods.

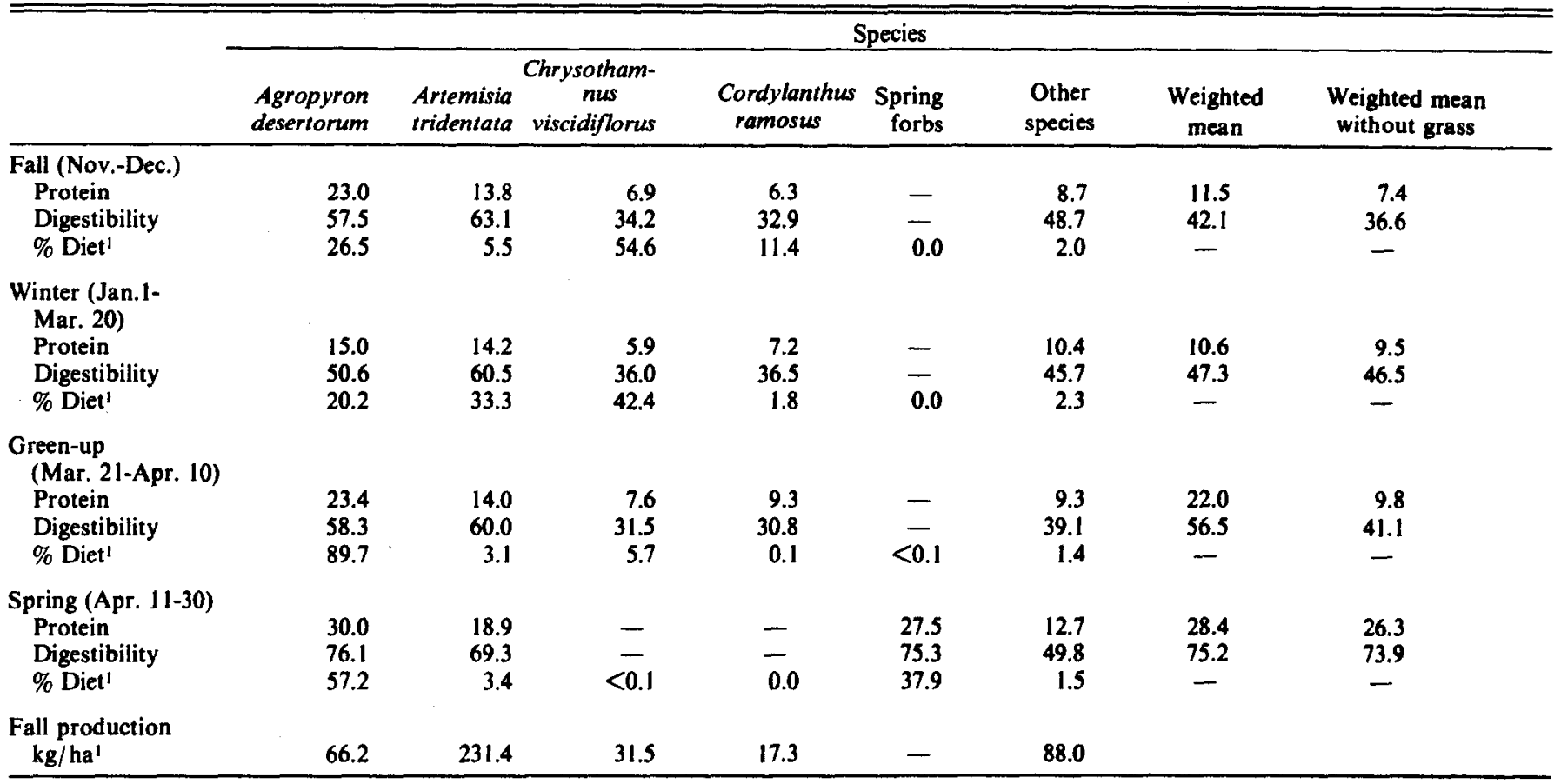

IData from: Austin, D.D., and P.J. Urness. In press. J. Wildl. Manage.

protein intake level 4.1 and $12.2 \%$, respectively. Digestibility was similarly increased during these periods. In mid-winter, when snow cover limited the availability of green grass and during spring with the increasing availability of palatable forbs, the qualitative advantage of grass in the diet was minor, even though grass constituted over $50 \%$ of the spring diet.

\section{Discussion}

The in vivo, in vitro, and field trials tended to be complementary. As would be expected, deer did not do as well physically under restrained in vivo conditions as under free ranging field conditions. This could partly be accounted for by the increased consumption under the field trial. Our figures indicated daily dry matter consumption of about $1.4 \mathrm{~kg} / 100 \mathrm{~kg}$ body weight of green crested wheatgrass would maintain body weight under field conditions.

The seasonal change in crude protein levels of crested wheatgrass followed the same pattern as described by Cook and Harris (1968) and Fierro (1977). However, even at its lowest values, the crude protein content was still excellent (Urness 1973) and far superior to most browse species (Smith 1952, Dietz et al. 1962) considered important in the winter diet of mule deer (Kufeld et al. 1973).

In conclusion, the availability of green crested wheatgrass significantly contributed to the overwinter nutrition of deer. It was particularly important during fall and spring periods. Utilization in fall would delay the mobilization of fat stores and use of browse until the critical mid-winter period. During severe winters when energy reserves in deer become exhausted, high quality forage, such as early growth of crested wheatgrass, becomes critically important to survival, more rapid recovery of body condition, and subsequent reproduction (Moen 1978).

\section{Literature Cited}

Altmann, J. 1974. Observational study of behaviors: sampling methods. Behaviour 47:227-265.

Ammann, A.P., R.L. Cowen, C.L. Mothershead, and B.R. Baumgardt. 1973. Dry matter and energy intake in relation to digestibility in whitetailed deer. J. Wildl. Manage. 37:195-201.

Austin, D.D., and P.J. Urness. In press. Overwinter forage selection by mule deer on a big sagebrush-grass range. J. Wildl. Manage.
Cook, C.W., and L.E. Harris. 1968. Nutritive value of seasonal ranges. Utah. Agr. Exp. Sta. Bull. 472.

Dietz, D.R., R.H. Udall, and L.E. Yeager. 1962. Chemical composition and digestibility by mule deer of selected forage species, Cache La Poudre Range, Colorado. Colorado Dep. Game and Fish Tech. Pub. 14.

Fierro, L.C. 1977. Influence of livestock grazing on the regrowth of crested wheatgrass for winter use by mule deer. Utah Wildl. Res. Pub. No. 77-17.

Hansen, R.M., and L.D. Reid. 1975. Diet overlap of deer, elk, and cattle in southern Colorado. J. Range Manage. 28:43-47.

Harris, L.E. 1970. Nutrition research techniques for wild and domestic animals. Vol. I. L.E. Harris, Pub. Logan, Utah.

Hungerford, C.R. 1970. Response of Kaibab mule deer to management of summer range. J. Wildl. Manage. 34:852-862.

Julander, 0.1958 . Techniques in studying competition between big game and livestock. J. Range Manage. 11:18-21.

Kufeld, R.C., O.V. Wallmo, and C. Feddema. 1973. Foods of the Rocky Mountain mule deer. USDA Forest Serv. Res. Pap. RM-111.

Leach, H.R. 1956. Food habits of the Great Basin deer herds of California. California Fish and Game 42:243-308.

Mautz, W.W. 1971. Confinement effects on dry matter digestibility coefficents displayed by deer. J. Wildl. Manage. 35:366-368.

Moen, A.N. 1978. Seasonal changes in heart rates, activity meta bolism, and forage intake of white-tailed deer. J. Wildl. Manage. 42:715-738.

Neff, D.J. 1974. Forage preferences of trained mule deer on the Beaver Creek watersheds. Arizona Game and Fish Dep. Spec. Rep. No. 4.

Plummer, A.P., D.R. Christensen, and S.B. Monsen. 1968. Restoring big game range in Utah. Utah Fish and Game Pub. No. 68-3.

Robinette, W.L., C.H. Baer, R.E. Pillmore, and C.E. Knittle. 1973. Effects of nutritional change on captive mule deer. J. Wildl. Manage. 37:312326.

Schoonveld, G.G., J.G. Nagy, and J.A. Bailey. 1974. Capability of mule deer to utilize fibrous alfalfa diets. J. Wildl. Manage. 38:823-829.

Short, H.L., D.E. Medin, and A.E. Anderson. 1965. Rumino-recticular characteristics of mule deer. J. Mammal. 46:196-199.

Smith, A.D. 1952. Digestibility of some native forages for mule deer. J. Wild. Manage. 16:308-312.

Tilley, J.M.A., and R.A. Terry. 1963. A two-stage technique for the in vitro digestion of forage crops. J. British Grassl. Soc. 18:104-111.

Trout, L.E., and J.L. Thiessen. 1973. Physical condition and range relationships of the Owyhee deer herd. Idaho Fish and Game Dep., Fed. Aid Proj. W-141-R, Job. Compl. Rep.

Urmess, P.J. 1973. Chemical analyses and in vitro digestibility of seasonal deer forages, part II, p. 39-52. In: Deer nutrition in Arizona chaparral and desert habitats. Arizona Game and Fish Dept. Spec. Rep. 3. 